\title{
? EARLY TERTIARY FOLD MOVEMENTS IN MULL
}

SIR,-In the correspondence published in the Geological Magazine vol. xcix, No. 5, Sir Edward Bailey has made some interesting comments on the peripheral folding in Mull discussed in a recent communication submitted by myself (Cheeney, 1962). In the first paragraph of his letter Sir Edward has correctly drawn attention to the indistinct division which I drew between my own researches and those of the Officers of the Geological Survey in the introductory sections of my paper. There is but one comment with which I would disagree. This is that my own " black and white map (p. 230) is almost identical with the coloured version in the Geological Survey one-inch Sheet 44 ". The black and white map referred to is necessarily a simplification of a map prepared on the scale of 6 inches to 1 mile yet, in spite of this simplification, the map shows new outcrops of Lorne Lavas and of conglomerate, supposedly Triassic.

Sir Edward goes on to say, in the third paragraph of his letter, that "It is impossible that so sharp a fold as the Loch Don Anticline could have been developed without important adjustments among (the) several formations concerned. It is next to impossible that these adjustments should fail to manifest themselves at some point or other along the contact of the relatively weak Mesozoic sediments and the relatively strong Tertiary lavas". I would agree with the first sentence and add that such adjustments, or faulting movements, might occur both along bedding planes and along surfaces inclined to the bedding as seen, for instance, in many oil-field sections. I would disagree however, with the statement that the Mesozoic rocks are "relatively weak" while the Tertiary lavas are "relatively strong" for the following reasons.

Apart from hydrothermal alteration the rocks have clearly undergone no significant metamorphism. Neither can they have been buried to any great depth. One may presume, therefore, that when the rocks were folded they were in much the same physical condition as they are at the present. The mechanism by which the adjustments or faults developed can thus be adequately accounted for in the terms of the theories of brittle fracture; the corresponding concepts of plasticity and viscocity being of minor importance. To gain some idea of the "relative strengths" of the Mesozoic and Tertiary rocks under such conditions we may compare such elastic constants as the modulus of rigidity or Young's modulus. Tables giving the values of these constants have been published (Birch et alia, 1942) and they demonstrated that there are no significant differences between limestones and sandstones on the one hand and basalts and allied rocks on the other. Biot (1961) pointed out that such differences in the elastic constants as do occur are probably unimportant in comparison with other physical properties. Orowan (1960) outlined theories of the origins of earthquakes and concludes that yield by brittle fracture is important only in the top 5 to $10 \mathrm{~km}$. of the Earth's crust : the provenance in which the folding in Mull most probably occurred. Griggs and others (1960) have presented the results of experiments on the deformation of rocks. They stated that " At $300^{\circ} \mathrm{C}$. and $5 \mathrm{~kb}$. confining pressure, the hard rocks - granite, peridotite, pyroxemite, basalt-are only slightly ductile. At $500^{\circ} \mathrm{C}$. and $5 \mathrm{~kb}$. all these have considerable ductility. Quartz and quartzite are still brittle, and remain so to $800^{\circ} \mathrm{C}$. and $5 \mathrm{~kb}$. even though at the latter temperature and pressure they have passed through the $a$ to $\beta$ conversion. At $500^{\circ} \mathrm{C}$. and above, at $5 \mathrm{~kb}$. none of the rocks tested except quartzite exhibits fracture, or sudden release of elastic stored energy." The possibility exists, therefore, that under certain conditions some of the Mesozoic sandstones may be "stronger" than the Tertiary basalt lavas.

Neither may we appeal to bedding planes in the Mesozoic rocks to account for a possible difference in "strength " because just as there are thick massive sandstones among the Mesozoic rocks so there are several thin platy lavas in the Tertiary sequence.

Sir Edward concludes his letter by saying that the approximate general parallelism of the margin of the Tertiary lavas with the stratification of the Jurassic is self-evident because the thickness of Jurassic rocks missing at the 
present level of erosion is relatively small. My alternative suggestion, which would also account for this parallelism of strike, depends on the orientation of the folds. The two folding episodes postulated (one before and the other later than the eruption of the Tertiary lavas) were very nearly co-axial. The fold axes are approximately horizontal so that, no matter how much the angles of dip in the two formations differed, their respective strikes would not be significantly different.

I do not dogmatically " reject a mechanical explanation" as Sir Edward has inferred. Maybe the margin between the Mesozoic and the Tertiary is faulted, but I think that the considerable angle of $60^{\circ}$ difference in dip between the two formations requires that some alternative explanation should be put forward.

\section{REFERENCES}

Balley, E. B., 1962. " ? Early Tertiary fold movements in Mull." Geol. Mag., 99, 478.

Bror, M. A., 1961. "Theory of folding of stratified viscoelastic media and its implications in tectonics and orogenesis." Bull. geol. Soc. Amer., 72, 1595.

BIRCH, F. et alia, 1942. "Handbook of physical constants." Geol. Soc. Amer. Special Paper No. 36.

Cheeney, R. F., 1962. "Early Tertiary fold movements in Mull." Geol. Mag., 99, 227.

Griggs, D. T., et alia, 1960. " Deformation of rocks at $500^{\circ}$ to $800^{\circ}$ C." Geol. Soc. Amer. Mem. 79.

Orowan, E., 1960. "Mechanism of seismic faulting." Geol. Soc. Amer. Mem. 79.

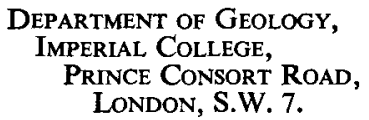

R. F. Cheeney.

14th January, 1963.

\section{CARBONIFEROUS GLACIATION IN GONDWANALAND}

SiR,-My attention has recently been drawn to a paper by M. M. Anderson (1961) dealing with the question of whether a phase of this glaciation appeared in northern Brazil and Ghana during the early Carboniferous, and drawing implications from what I wrote in a synthetic paper upon this glaciation in Gondwanaland as a whole (1958) to which I would certainly not subscribe.

The original references were to Junner $(1939,1940)$ for glaciation in Ghana and Caster (1952) for glaciation on the Lower Tapajoz in Brazil (see below). As Anderson states, Crow (1952) has since expressed a view different from Junner (which I overlooked), but so far as I know Caster's record still stands. Anderson writes :

"King considered (1958) that the Permo-Carboniferous glaciations began in North Brazil and Ghana. Thus he states that the great glaciations began in the early Carboniferous of Brazil and the Gold Coast".

The original passage was: "The great glaciations began in the early Carboniferous : " then a number of occurrences were mentioned, all in the same paragraph, from the Lower Tapajoz of Brazil and the Ajua shales of Ghana to western Argentina. This is merely a convenient geographical order of description, there is no statement that the glaciation began in the north, nor was such intended. If there was an ice sheet all the northern occurrences were probably peripheral, and Junner (1940) mentioned " The scattered very large boulders .... and the recumbent folds and overfolds in the calcareous shales ... may have been caused by icebergs". In a publication the previous year he had also referred to "varves" in the Ajua shales, which again infers a 